\title{
ABSTRAK \\ PENERAPAN STRATEGI PEMBELAJARAN THINK PAIR SHARE UNTUK MENINGKATKAN MOTIVASI BELAJAR BIOLOGI SISWA KELAS X-KPR-2 SMKN 13 KOTA MALANG
}

\author{
Husnul Chotimah, Guru Biologi SMKN 13 Kota Malang \\ E-mail: husnulchotimah.67@gmail.com
}

\begin{abstract}
Siklus I, nilai motivasi belajar biologi tergolong cukup yaitu 56,13. Variabel motivasi belajar attention (perhatian) diperoleh nilai 54,00, relevance (keterkaitan) diperoleh nilai 56,6, confidence (kepercayaan) diperoleh nilai 58,25, dan satisfaction (kepuasan) diperoleh nilai 55,67. Siklus II, nilai motivasi belajar biologi tergolong tinggi yaitu 70,48. Pada variabel motivasi belajar attention (perhatian) diperoleh nilai 63,96, relevance (keterkaitan) diperoleh nilai 68,98, confidence (kepercayaan) diperoleh nilai 74,31 , dan satisfaction (kepuasan) diperoleh nilai 74,70. Berdasarkan nilai motivasi belajar pada siklus I dan siklus II, dapat disimpulkan bahwa strategi pembelajaran think pair share mampu meningkatkan motivasi belajar biologi siswa kelas X-KPR-2 SMKN 13 Malang.
\end{abstract}

Kata Kunci: motivasi, tps

Pendidikan merupakan salah satu aspek yang berperan penting dalam peningkatan kualitas sumber daya manusia. Oleh karena itu, perwujudan dan peningkatan kualitas pendidikan merupakan hal yang harus dilakukan. Peningkatan kualitas pendidikan di sekolah, tidak lepas dari tugas guru baik sebagai pendidik maupun sebagai pengajar. Menurut Sagala (2009), pendidikan berusaha mengembangkan seluruh aspek kepribadian dan kemampuan manusia, baik dilihat dari aspek kognitif, afektif, dan psikomotorik. Sementara itu, pengajaran merupakan sarana yang ampuh dalam menyelenggarakan pendidikan sehingga permasalahan-permasalahan dalam pendidikan dapat teratasi dengan baik.

Salah satu permasalahan yang terjadi di SMKN 13 Malang, khususnya siswa kelas X-Keperawatan (KPR)-2 adalah rendahnya motivasi belajar biologi. Berdasarkan hasil survei dengan angket, yang diberikan pada siswa kelas X-KPR-2, diperoleh data bahwa motivasi belajar biologi tergolong rendah yaitu 46,53. Pada variabel motivasi belajar attention (perhatian) diperoleh nilai rata-rata 44,44 yang terdiri atas indikator 
rasa senang terhadap pelajaran diperoleh nilai sebesar 49,20, rasa ingin tahu 38,40, perhatian terhadap tugas 42,60, ketepatan waktu menyelesaikan tugas 43,40, dan ketenangan di kelas diperoleh nilai 48,60. Pada variabel motivasi belajar relevance (keterkaitan) diperoleh nilai rata-rata 48,74 yang terdiri atas indikator memahami apa yang dipelajari dalam pembelajaran dengan nilai 44,40, keterkaitan materi yang disampaikan dengan apa yang telah dipelajari sebesar 49,40, materi pelajaran sesuai dengan keinginan 49,20, mengkaitkan pelajaran dengan kehidupan sehari-hari sebesar 48,80 , kesesuian metode belajar 50,60, perasaan terdorong dalam belajar diperoleh nilai 51,20, dan kegunaan materi ajar sebesar 47,60. Pada variabel motivasi belajar confidence (kepercayaan) diperoleh nilai rata-rata 46,52, yang terdiri atas indikator keyakinan akan berhasil dengan nilai 45,20, keyakinan terhadap materi pelajaran 54,20, keyakinan dapat memahami pelajaran 49,60, memiliki cita-cita sebesar 56,60, membaca buku lain yang dapat mendukung pelajaran biologi tergolong rendah yaitu diperoleh nilai 33,80, dan percaya diri sebesar 39,70. Pada variabel motivasi belajar satisfaction (kepuasan) diperoleh nilai rata-rata 46,41, yang terdiri atas indikator kepuasan terhadap hasil belajar sebesar 46,30, senang atas reinforcement 51,60, kesediaan membantu teman yang belum berhasil sebesar 43,80, kehadiran di kelas sebesar 34,20, keinginan berprestasi 53,10, kesenangan dalam belajar 49,20, kepuasan setiap mengikuti pelajaran biologi 44,20, dan merasa puas setiap tes juga tergolong rendah yaitu diperoleh nilai sebesar 48,90.

Beberapa faktor penyebab rendahnya motivasi belajar siswa yaitu: (1) kurang memiliki keinginan untuk berprestasi karena targetnya hanya lulus dan langsung bekerja, (2) kurang berminat belajar biologi karena bukan mata pelajaran yang diujikan di tingkat nasional, dan (3) kurang termotivasi belajar karena mata pelajaran biologi bukan mata pelajaran produktif (Chotimah, 2014). Motivasi belajar ini perlu ditingkatan karena sejalan dengan salah satu standar kompetensi lulusan untuk perawat kesehatan yaitu melakukan komunikasi interpersonal dalam melaksanakan tindakan keperawatan.

Selama ini, guru telah melakukan berbagai upaya untuk meningkatkan motivasi belajar siswa dalam pembelajaran biologi di antaranya dengan (1) mengamati tayangan video materi yang bersifat mikroskopis, (2) mengikuti forum musyawarah guru 
matapelajaran, untuk sharing tentang proses pembelajaran, (3) berupaya melaksanakan pembelajaran dengan menggunakan strategi pembelajaran kooperatif, namun upaya tersebut belum memperoleh hasil yang optimal sehingga perlu dilakukan perbaikan.

Salah satu strategi pembelajaran kooperatif yang dapat menciptakan suasana kebersamaan dalam pembelajaran biologi adalah think pair share. Pembelajaran dengan strategi pembelajaran kooperatif think pair share (TPS) diharapkan dapat menjadi alternatif dalam mengatasi permasalahan pembelajaran biologi. Strategi pembelajaran think pair share diharapkan dapat meningkatkan motivasi belajar karena motivasi belajar sangat diperlukan untuk dimiliki oleh siswa jenjang SMK. Alasan pemilihan strategi think pair share untuk diterapkan dalam pembelajaran biologi SMK karena strategi pembelajaran kooperatif TPS: (1) memiliki langkah-langkah yang mudah untuk dilakukan, (2) mudah diterapkan di berbagai aktivitas pembelajaran di kelas maupun di laboratorium, (3) merupakan strategi pembelajaran yang sederhana, (4) memberikan kesempatan partisipasi yang sama (equal participation), artinya masing-masing anggota kelompok memiliki kesempatan sama untuk sharing, dan (5) memungkinkan terjadi interaksi secara bersamaan yang intensif, baik itu mengemukakan pendapat maupun mendengarkan pendapat anggota kelompok.

Strategi pembelajaran TPS merupakan salah satu pembelajaran kooperatif yang menekankan adanya proses berpikir (thinking), berkelompok dan berpasangan (pairing) dan berbagi (sharing). Hasil penelitian sebelumnya menunjukkan bahwa pembelajaran TPS maupun perpaduan TPS dengan strategi lain membantu siswa meningkatkan motivasi belajar, minat dan kerja sama anggota dalam kelompok (Chotimah, 2007). Berdasarkan pandangan dan identifikasi masalah yang telah diuraikan sebelumnya, maka dilakukan penelitian tindakan kelas dengan menerapkan strategi think pair share dalam pembelajaran biologi sebagai upaya untuk meningkatkan motivasi belajar siswa kelas X-KPR-2 tahun pelajaran 2014-2015 semester 2 di SMKN 13 Malang.

\section{METODE PENELITIAN}

Rancangan penelitian menggunakan penelitian tindakan kelas (PTK) atau classroom action research dengan pendekatan kualitatif. Dalam PTK terdapat tindakan- 
tindakan untuk perbaikan kegiatan pembelajaran yaitu proses maupun peningkatan kualitas ataupun hasil belajar. Desain penelitian yang digunakan mengacu pada model Kemmis dan M.C Taggart (1988) yang terdiri dari empat komponen yaitu: perencanaan, tindakan, observasi dan refleksi. Penelitian dilakukan sebanyak dua siklus, masingmasing siklus sebanyak tiga kali pertemuan.

Tahap awal dalam penelitian ini adalah: (1) Peneliti melakukan pertemuan dengan dua orang guru biologi SMKN 13 Kota Malang. Dalam pertemuan tersebut peneliti menyampaikan bahwa akan melaksanakan PTK dengan menerapkan strategi think pair share, (2) peneliti menunjukkan perangkat pembelajaran berupa: rencana pelaksanaan pembelajaran (RPP), denah tempat duduk siswa, dan angket motivasi serta meminta dua orang guru biologi tersebut membantu menjadi observer saat pelaksanaan tindakan, (3) Peneliti menyampaikan subjek penelitian berdasarkan kriteria yang ditetapkan. Subjek penelitian adalah 1 (satu) kelas yang berjumlah 30 siswa kelas X jurusan keperawatan (X KPR-2) tahun pelajaran 2014/2015.

Metode pengumpulan data berupa: (1) wawancara, (2) observasi, dan (3) catatan lapangan. Dalam penelitian ini peneliti membuat instrumen berupa angket untuk mengukur motivasi belajar. Motivasi belajar mengacu pada model ARCS (Keller, 2010) yang terdiri dari Attention dengan lima deskriptor yaitu: (1) rasa senang terhadap pelajaran (2) rasa ingin tahu, (3) perhatian terhadap tugas, (4) ketepatan waktu menyelesaikan tugas, dan (5) ketenangan di kelas, Relevance dengan tujuh deskriptor yaitu: (1) memahami apa yang dipelajari dalam pembelajaran, (2) keterkaitan materi yang disampaikan dengan apa yang telah dipelajari, (3) materi pelajaran sesuai dengan keinginan, (4) mengkaitan pelajaran dengan kehidupan sehari-hari, (5) kesesuaian metode belajar, (6) perasan terdorong dalam belajar, (7) kegunaan materi ajar, Confidence dengan enam deskriptor yaitu: (1) keyakinan akan berhasil, (2) keyakinan terhadap materi pelajaran, (3) keyakinan dapat memahami pelajaran, cita-cita, (5) membaca buku lain yang dapat mendukung pelajaran biologi, dan (6) percaya diri, dan Satisfaction dengan delapan deskriptor yaitu: (1) kepuasan terhadap hasil belajar, (2) senang atas reinforcement, (3) kesediaaan membantu teman yang belum berhasil, (4) kehadiran di kelas, (5) keinginan berprestasi, (6) kesenangan dalam belajar, (7) 
kepuasan setiap mengikuti pelajaran, dan (8) merasa puas setiap tes. Sebelum pelaksanan penelitian, telah dilakukan ujicoba untuk menentukan validitas instrumen motivasi belajar.

Data motivasi belajar diukur dengan menggunakan angket motivasi, dianalisis secara kuantitatif dengan menggunakan analisis statistik deskriptif. Analisis bertujuan untuk mengetahui motivasi belajar siswa berdasarkan indikator motivasi yang telah ditentukan. Langkah-langkah menganalisisnya sebagai berikut.

a) Menghitung jumlah skor dari pilihan siswa, baik pernyataan positif maupun pernyataan negatif.

b) Menghitung persentase motivasi dengan membagi jumlah skor motivasi perolehan siswa dengan jumlah skor maksimal.

c) Menghitung nilai motivasi belajar dengan membagi jumlah perolehan dengan banyaknya item pada angket motivasi pada setiap indikator.

d) Dinyatakan dengan rumus:

Nilai motivasi belajar $=\frac{\text { Skor totaly ang diperoleh }}{\text { Skor totalitem kuesioner }} \times 100 \%$

\section{PELAKSANAAN TINDAKAN}

PTK dengan menerapkan strategi think pair share dalam pembelajaran biologi, pada tahap tindakan terdiri atas dua siklus, masing-masing siklus sebanyak tiga pertemuan. Dilaksanakan bulan Februari sampai dengan bulan Maret 2015, pada siswa kelas X-KPR-2 SMKN 13 Kota Malang sejumlah 30 orang. Pada siklus I pertemuan pertama berlangsung sebagai berikut. (1) Pada kegiatan awal pembelajaran, guru mengecek artikel tentang Virus yang dibawa siswa dan meminta siswa mengerjakan tugas secara individu (think) yaitu: membaca dan menuliskan ciri-ciri virus dan cara reproduksi virus berdasarkan hasil bacaannya pada lembar jawaban tahap think, (2) berdasarkan hasil bacaan, mendiskusikan ciri-ciri virus dan cara reproduksi virus, bersama teman sebangku (pair), saling melengkapi dengan menambah pengetahuan dari berbagai sumber selain hand out yang diperoleh dari guru, (3) menggambar bentuk virus yang terdapat dalam artikel dan memberi nama bagian-bagiannya dan 
menggambar cara reproduksi virus. Semua hasil diskusi tahap pair ditulis pada lembar jawaban tahap pair. Pertemuan pertama pembelajaran ditutup oleh guru dengan meminta siswa mempelajari kembali ciri-ciri virus dan cara reproduksi virus serta mempelajari peranan virus sebagai lanjutan materi yang akan dipelajari pada pertemuan selanjutnya.

Siklus I pertemuan kedua sebagai berikut. (1) Kegiatan awal pembelajaran guru meminta siswa secara bergantian mempresentasikan ciri-ciri virus dan cara reproduksi virus yang telah mereka pelajari pada pertemuan sebelumnya (Share). Selanjutnya, guru membagi siswa menjadi 7 kelompok masing-masing kelompok beranggotakan 4-5 orang yang memiliki kemampuan akademik heterogen, (2) Guru membagikan lembar jawaban tahap share kepada masing-masing kelompok, dan meminta masing-masing kelompok mendiskusikan peranan virus berdasarkan artikel yang telah mereka bawa (3) guru meminta siswa wakil kelompok mempresentasikan hasil diskusinya (share).

Siklus I pertemuan ke tiga guru membagikan angket motivasi belajar yang berisi 52 pernyataan sesuai indikator model motivasi ARCS (Keller, 1983) yang terdiri dari Attention (perhatian), Relevance (keterkaitan), Confidence (kepercayaan), dan Satisfaction (kepuasan).

Kegiatan Pembelajaran pada siklus II berlangsung sebagai berikut. (1) Guru mengecek artikel tentang Bakteri yang dibawa siswa dan meminta siswa mengerjakan tugas secara individu (think) yaitu: membaca dan menuliskan ciri-ciri bakteri dan cara reproduksi bakteri berdasarkan hasil bacaannya pada lembar jawaban tahap think, (2) berdasarkan hasil bacaan, mendiskusikan ciri-ciri bakteri dan cara reproduksi bakteri, bersama teman sebangku (pair), saling melengkapi dengan menambah pengetahuan dari berbagai sumber selain hand out yang diperoleh dari guru, (3) menggambar macammacam bentuk bakteri yang terdapat dalam artikel dan memberi nama bagian-bagiannya dan menggambar cara reproduksi bakteri. Semua hasil diskusi tahap pair ditulis pada lembar jawaban tahap pair. Pertemuan pertama pembelajaran ditutup oleh guru dengan meminta siswa mempelajari kembali ciri-ciri bakteri dan cara reproduksi bakteri serta mempelajari peranan bakteri sebagai lanjutan materi yang akan dipelajari pada pertemuan selanjutnya. 
Siklus II pertemuan kedua sebagai berikut. (1) Kegiatan awal pembelajaran guru meminta siswa secara bergantian mempresentasikan ciri-ciri bakteri dan cara reproduksi bakteri yang telah mereka pelajari pada pertemuan sebelumnya (Share). Selanjutnya, guru membagi siswa menjadi 7 kelompok masing-masing kelompok beranggotakan 4-5 orang yang anggotanya berbeda dengan kelompok saat siklus I, (2) Guru membagikan lembar jawaban tahap share kepada masing-masing kelompok, dan meminta masingmasing kelompok mendiskusikan peranan bakteri berdasarkan artikel yang telah mereka bawa (3) guru meminta siswa wakil kelompok mempresentasikan hasil diskusinya (share).

Siklus II pertemuan ke tiga guru membagikan angket motivasi belajar yang berisi 52 pernyataan sesuai indikator model motivasi ARCS. Pada saat pembelajaran, peneliti ditemani oleh dua guru biologi yang bertindak sebagai observer.

\section{HASIL PENELITIAN}

Pembelajaran biologi dapat dilakukan dengan menerapkan strategi think pair share. Strategi think pair share (TPS) adalah suatu strategi diskusi kooperatif yang dikembangkan oleh Frank Lyman dan kawan-kawannya di Universitas Maryland pada tahun 1981. TPS memperkenalkan ide "waktu berpikir atau waktu tunggu" dalam meningkatkan kemampuan siswa merespon pertanyaan. Nama Think-Pair-Share berasal dari tiga tahap kegiatan siswa yang menekankan pada apa yang dikerjakan siswa pada setiap tahap (Jones, 2002).

TPS merupakan salah satu strategi dari kooperatif. Langkah-langkah dalam pembelajaran kooperatif TPS menurut Arends (2008) dan Ledlow (2001) sebagai berikut: (1) tahap pertama yaitu think (berpikir). Pada tahap ini guru memancing siswa untuk berpikir melalui pertanyaan-pertanyaan atau observasi (pengamatan). Siswa berpikir sejenak tentang apa yang ditanyakan oleh guru, (2) tahap kedua yaitu pair (berpasangan). Pada tahap ini siswa berdiskusi mengenai jawaban pertanyaan guru pada tahap think secara bersama-sama dan memiirkan jawaban terbaik dari hasil diskusi. Pasangan didapat dari teman sebangku atau siswa lain yang terdekat, dan (3) tahap ketiga yaitu share (berbagi). Pada tahap share, siswa mempresentasikan jawabannya di 
depan kelas agar semua siswa mengetahuinya. Pada tahap ini guru mencata respon siswa di papan tulis.

Pada kegiatan pembelajaran materi virus dan bakteri, guru melaksanakan pembelajaran dengan menerapkan strategi TPS. Siswa memahami materi pembelajaran secara mandiri (tahap think), berdua dengan teman sebangku (tahap pair) dan mengkomunikasikan dengan teman di kelas (tahap share) semua proses tersebut merupakan proses siswa "mengalami” bukan “diberitahu”. Siswa bertanggungjawab terhadap pembelajaran mereka, sedangkan guru bertugas memfasilitasi dan memotivasi siswa untuk belajar. Perbedaan pada kedua siklus adalah materi yang dipelajari tidak sama, dan perbedaan teman sebangku (tahap pair) serta teman dalam satu kelompok.

Pada masing-masing siklus guru meminta siswa membawa artikel tentang materi yang akan dipelajari untuk memudahkan siswa mengerjakan tugas dari guru. Tugas dari guru semakin terasa mudah manakala mereka belajar dengan teman kelompoknya. Kegiatan ini merupakan salah satu ciri pembelajaran kooperatif. Pembelajaran kooperatif mengutamakan kerjasama dalam menyelesaikan masalah untuk menerapkan pengetahuan dan keterampilan dalam rangka mencapai tujuan pembelajaran. Pembelajaran kooperatif mendorong siswa untuk bekerjasama pada suatu tugas bersama dan mereka harus mengoordinasikan usahanya untuk menyelesaikan tugas yang diberikan guru. Slavin (2008) mengemukakakan empat prinsip dasar dari pembelajaran kooperatif, yaitu: (1) interaksi siswa yang berkelanjutan, (2) saling ketergantungan yang positif, (3) akuntabilitas individu, dan (4) partisipasi setara.

Proses belajar siswa pada siklus I dan II, diakhiri dengan memberikan angket motivasi belajar untuk mengukur motivasi belajar biologi siswa kelas X-KPR-2. Pada siklus I, nilai motivasi belajar biologi tergolong cukup yaitu 56,13. Pada variabel motivasi belajar attention (perhatian) diperoleh nilai 54,0 yang terdiri atas indikator rasa senang terhadap pelajaran diperoleh nilai sebesar 59,2, rasa ingin tahu 45,6 perhatian terhadap tugas 56,2, ketepatan waktu menyelesaikan tugas 53,4, dan ketenangan di kelas diperoleh nilai 58,6. Pada variabel motivasi belajar relevance (keterkaitan) diperoleh nilai rata-rata 56,6 yang terdiri atas indikator memahami apa yang dipelajari dalam pembelajaran dengan nilai 52,2, keterkaitan materi yang disampaikan dengan 
apa yang telah dipelajari sebesar 59,4, materi pelajaran sesuai dengan keinginan 63,9, mengkaitkan pelajaran dengan kehidupan sehari-hari sebesar 58,8, kesesuian metode belajar 53,1, perasaan terdorong dalam belajar diperoleh nilai 51,2, dan kegunaan materi ajar sebesar 57,6. Pada variabel motivasi belajar confidence (kepercayaan) diperoleh nilai rata-rata 58,25, yang terdiri atas indikator keyakinan akan berhasil dengan nilai 55,4 , keyakinan terhadap materi pelajaran 54,2, keyakinan dapat memahami pelajaran 59,8, memiliki cita-cita sebesar 56,6, membaca buku lain yang dapat mendukung pelajaran biologi diperoleh nilai 53,8, dan percaya diri sebesar 69,7. Pada variabel motivasi belajar satisfaction (kepuasan) diperoleh nilai rata-rata 55,67 yang terdiri atas indikator kepuasan terhadap hasil belajar sebesar 56,3, senang atas reinforcement 51,6, kesediaan membantu teman yang belum berhasil sebesar 63,8, kehadiran di kelas sebesar 54,7, keinginan berprestasi 53,1, kesenangan dalam belajar 52,2, kepuasan setiap mengikuti pelajaran biologi 54,3 , dan merasa puas setiap tes diperoleh nilai sebesar 59,4.

Pada siklus II, nilai motivasi belajar biologi tergolong tinggi yaitu 70,48. Pada variabel motivasi belajar attention (perhatian) diperoleh nilai 63,96 yang terdiri atas indikator rasa senang terhadap pelajaran diperoleh nilai sebesar 65,9, rasa ingin tahu 68,8 , perhatian terhadap tugas 72,4 , ketepatan waktu menyelesaikan tugas 53,8 , dan ketenangan di kelas diperoleh nilai 58,9. Pada variabel motivasi belajar relevance (keterkaitan) diperoleh nilai rata-rata 68,98 yang terdiri atas indikator memahami apa yang dipelajari dalam pembelajaran dengan nilai 57,9, keterkaitan materi yang disampaikan dengan apa yang telah dipelajari sebesar 67,4, materi pelajaran sesuai dengan keinginan 79,7, mengkaitkan pelajaran dengan kehidupan sehari-hari sebesar 68,7 , kesesuian metode belajar 80,4, perasaan terdorong dalam belajar diperoleh nilai 61,2, dan kegunaan materi ajar sebesar 67,6. Pada variabel motivasi belajar confidence (kepercayaan) diperoleh nilai rata-rata 74,31, yang terdiri atas indikator keyakinan akan berhasil dengan nilai 72,4, keyakinan terhadap materi pelajaran 85,4 , , keyakinan dapat memahami pelajaran 69,9, memiliki cita-cita sebesar 75,5, membaca buku lain yang dapat mendukung pelajaran biologi diperoleh nilai 68,8, dan percaya diri sebesar 73,9. Pada variabel motivasi belajar satisfaction (kepuasan) diperoleh nilai rata-rata 74,7 
yang terdiri atas indikator kepuasan terhadap hasil belajar sebesar 86,3, senang atas reinforcement 61,6, kesediaan membantu teman yang belum berhasil sebesar 63,8, kehadiran di kelas sebesar 84,6, keinginan berprestasi 73,1, kesenangan dalam belajar 79,2 , kepuasan setiap mengikuti pelajaran biologi 74,2, dan merasa puas setiap tes diperoleh nilai sebesar 74,8 .

\section{PEMBAHASAN}

Berdasarkan hasil pengamatan observer, kegiatan pembelajaran pada siklus I dan II telah mampu membuat siswa termotivasi untuk belajar. Mereka melakukan aktivitas pembelajaran dengan baik. Waktu berpikir atau waktu tunggu yang diberikan oleh guru pada tahap think merupakan hal positif dalam melayani siswa belajar, karena siswa diberi waktu untuk berpikir sebelum mereka menjawab pertanyaan/mengerjakan tugas. Pada tahap ini siswa mencoba "memikirkan" pertanyaan/tugas dan berusaha secara mandiri menjawab/mengerjakan tugas dari guru.

Pembelajaran kooperatif merupakan pembelajaran yang menekankan adanya saling ketergantungan positif antar siswa sehingga setiap siswa dengan berbagai potensinya didayagunakan dalam menyelesaikan permasalahan yang sedang dipelajari. Pembelajaran kooperatif bukanlah pembelajaran yang memunculkan sosok individu tertentu melainkan memunculkan keberhasilan kelompok atas partisipasi aktif dari individu dalam kelompok. Corebima, (2002) menyatakan, bahwa semua model mengajar yang ditandai dengan adanya struktur tugas, struktur tujuan dan reward (penghargaan). Struktur tugas lebih mengacu kepada seting cara pembelajaran dan jenis kegiatan yang dilakukan siswa di kelas. Pada pembelajaran kooperatif, terjadi saling ketergantungan antara siswa yang satu dengan siswa yang lain pada saat mereka mengerjakan tugasnya. Masing-masing siswa ikut andil menyumbangkan pencapaian tujuan dalam pembelajaran.

\section{KESIMPULAN}

Dari hasil penelitian yang dilakukan dalam dua siklus, dapat disimpulkan bahwa penerapan strategi pembelajaran think pair share dalam pembelajaran biologi dapat 
meningkatkan motivasi belajar pada siswa kelas X-KPR-2 SMKN 13 Kota Malang. Hal tersebut dapat dibuktikan dengan adanya peningkatan nilai motivasi belajar dari siklus I ke siklus II pada masing-masing indikator. Saran yang diajukan seyogyanya strategi pembelajaran think pair share dipakai dalam pembelajaran mata pelajaran lain sebagai alternatif untuk meningkatkan mutu pembelajaran.

\section{SARAN}

Motivasi merupakan salah satu faktor yang dapat menentukan kesuksesan siswa dalam proses pembelajaran. Siswa dengan motivasi yang besar akan giat berusaha, tampak gigih tidak mudah menyerah, sebaliknya mereka yang motivasinya rendah tampak acuh tak acuh, mudah putus asa, perhatiannya tidak tertuju pada pelajaran sehingga mengalami kesulitan belajar yang dapat berakibat fatal bagi dirinya dalam artian prestasinya akan semakin menurun.

Tugas guru adalah bagaimana mendorong para siswa agar pada dirinya tumbuh motivasi belajar. Dalam hal ini, guru harus dapat menciptakan kondisi dan strategi pembelajaran tertentu agar siswa dapat memperoleh prestasi belajar maksimal. Salah satu strategi pembelajaran tersebut adalah think pair share, yang terbukti mampu meningkatkan motivasi belajar siswa yang pada akhirnya akan meningkatkan prestasi belajar.

\section{DAFTAR RUJUKAN}

Arends. 2008. Learning To Teach. Terjemahan oleh Soecipto. Pustaka Pelajar. Yogjakarta:

Chotimah, H. 2007. Peningkatan Proses dan Hasil Belajar Biologi dalam Pendekatan Kontekstual melalui Model Pembelajaran Think Pair Share pada Peserta Didik Kelas X-6 SMA Laboratorium Universitas Negeri Malang. Penelitian Tindakan Kelas. Tidak diterbitkan.

Chotimah, Husnul. 2014. Refleksi Implementasi Kurikulum 2013 dan Analisis Kebutuhan Bahan Ajar Biologi SMK se Kota Malang. Makalah disampaikan pada Seminar \& Workshop Nasional Biologi/IPA dan Pembelajarannya di FMIPA Universitas Negeri Malang Tanggal 1 November 2012.

Corebima, A.D. 2002. Pemberdayaan Berpikir Melalui Pertanyaan (PBMP) sebagai Alat Pembelajaran IPA Biologi Konstruktivis untuk Meningkatkan Penalaran Siswa SLTP di Jawa Timur. Laporan RUT VIII. KantorMenteri Negara Riset dan Teknologi. 
Jones, R. C. 2002. Strategis For Reading Comprehension Think Pair Share. (Online), (http//curry.edschool.virginia.edu/go.id) di akses 24 Desember 2014.

Keller, John. M. 2010. Motivational Design for Learning and Performance: The ARCS Model Approach. Springer. London.

Kemmis, S \& Mc. Taggart, R. 1988. The Action Research Planner. Deakin University Press. Victoria

Ledlow, S. 2001. Using Think-Pair-Share in The College Classroom. Arizona State University. USA.

Nur, M. 2003. Pemotivasian Siswa untuk Belajar. Surabaya: Pusat Sains dan Matematika Sekolah (PSMS). Universitas Negeri Surabaya.

Safari. 2005. Penulisan Butir Soal Berdasarkan Penilaian Berbasis Kompetensi. Depdiknas. Jakarta.

Sagala, Syaiful. 2009. Konsep dan Makna Pembelajaran. Alfabeta. Bandung.

Slavin, R.E. 2008. Cooperative Learning Theory, Research and Practice. $2^{\text {nd }}$ Ed. Allyn and Bacon. Boston. London, Toronto, Sydney, Tokyo, Singapore. 